\title{
Kisebbségek, kohézió és az információs társadalom
}

Az ipari társadalomból a tudásalapú információs társadalomba való átmenet átstrukturálja a társadalmi egyenlőtlenségek rendszerét, esélyt adva a hátrányos helyzetű csoportok felemelkedésére és ezáltal a társadalmi kohézió erősödésére. Átrendeződik a gazdaság, megváltoznak az emberek közötti érintkezési viszonyok, új erőforrások kerülnek előtérbe. A tudás mint kulturális tőke és az emberi kapcsolatok hálózata mint társadalmi tőke a materiális tőkével azonos fontosságúvá válik. A tanulmány szerzője az info-kommunikációs eszközök lehetőségeit vizsgálja a versenyképességet javító tudás és a gazdasági sikerességhez nélkülözhetetlen bizalmon alapuló együttműködés terén. Néhány sikeres példán keresztül rámutat, hogy a kohézió megőrzésének egyik kulcskérdése a leszakadó térségek és társadalmi csoportok bekapcsolódása az információs társadalomba, a hozzáférési esélyek és a motiváltság erősítése révén.

Kulcsszavak: társadalmi kohézió, kisebbségek, információs társadalom, hálózati típusú emberi kapcsolatok, depriváltak, társadalmi kirekesztődés, versenyképesség: tudásalapú versenyképesség

\section{Szerzői információ:}

Pankucsi Márta

Jogász (Pécsi Tudományegyetem, 1977), az ELTE-n filozófiai és szociológiai végzettséget is szerzett. A Miskolci Egyetemen szociológiát tanított, majd a Népjóléti Minisztérium szóvivôje lett. Dolgozott a Múvelődési és Közoktatási Minisztérium civil kapcsolatokért felelôs igazgatójaként és az ELTE külső előadójaként. Jelenleg a ME Szociológia Tanszékének tanszékvezetôje, a Társadalomkutató Kihelyezett Központ igazgatója és az ott múködő ITTK vezetôje. Kutatási témái: a politikai hatalom legitimációja, a civil társadalom szerveződése, kisebbségi jogok, helyi erőforrások, hagyományos és infokommunikációs kapcsolati hálózatok

E-mail: bolmpszo@uni-miskolc.hu

Így hivatkozzon erre a cikkre:

Pankucsi Márta. „Kisebbségek, kohézió és az információs társadalom”. Információs Társadalom VI, 2. szám (2006): 86-97. 
Pankucsi Márta

\section{Kis e b bségek, kohézió és az információs társadalom}

\section{Versenyképesség és társadalmi kohézió}

A 2005 ôszén Párizsban és más francia városokban bekövetkezett lázadások rendkívül radikálisan és mindenki számára érzékelhetốen hívták fel a figyelmet a társadalmi kohézió fontosságára. Az integráltnak tűnő nyugat-európai társadalomban kitört zavargások ellehetetlenítették a társadalom normális múködését, megzavarták az emberek megszokott mindennapi életének a rendjét. Az események foószereplói olyan fiatalok voltak, akik afrikai bevándorlók leszármazottai, a külvárosok lepusztult lakótelepein élnek, iskolázatlanok, munkanélküliek, és bár már Franciaországban születtek és francia állampolgárok, mégis elkülönülő csoportokat alkotnak.

A zavargásokat kirobbantó ok az volt, hogy egy bưncselekmény elkövetóinek üldözésére indult rendốrségi akció elól két társuk egy trafóházba menekült, ahol halálos áramütés érte óket. Ezt követốen heteken át éjszakánként személygépkocsik százait gyújtották fel, és más cselekményeikkel lehetetlenítették el a megszokott életet. A társadalmi egyenlőtlenségek rendszerének legalsó szintjén található csoportok abban az esetben szoktak ilyen és ehhez hasonló módokon szembefordulni a társadalom többségével, ha nincs esélyük arra, hogy a társadalom által elfogadott eszközökkel változtassanak helyzetükön, vagyis ha az egyéni mobilizáció, az elóbbre jutás kilátástalan vagy kilátástalannak tưnik az érintettek számára. Ilyen esetekben törnek ki éhséglázadások az élelemért, forradalmak a hatalomért, és más erôszakos cselekmények a leginkább hiányzó javak megszerzéséért.

A 2005 ószén autókat gyújtogató fiatalok közül többen azzal indokolták tetteiket, hogy „be akartak kerülni a tv-be”. Anélkül, hogy módunkban állna feltárni az események tényleges motívumait, érdemes elgondolkodnunk ezeken a válaszokon. Lehetséges, hogy korunkban a televíziós szereplés, a nyilvánossághoz jutás, az információs társadalomba történố bekapcsolódás olyan értékeket képviselnek, amelyekhez bizonyos társadalmi csoportok egyáltalán nem juthatnak hozzá, erre esélyük sincs. Lehet, hogy ezen értékek bárki általi megszerezhetôsége, a hozzáférés biztosítása jelenti ma a társadalmi felemelkedés egyéni és kollektív esélyét? Lehet, hogy az információs társadalomba történố bekapcsolódás égetố szükségletté vált és az attól való megfosztottság válhat a társadalom széteséséhez vezetô erôszakos megmozdulások mozgatójává? Feltételezhetjük, hogy a párizsi gyújtogató fiatalok a televízióban nem egyszerúen a figyelemfelhívás hatékony eszközét látták, hanem az számukra ma ugyanolyan mozgósító erejü, bárminek az elkövetését megérố cél, amilyen elődeik számára a sportautóval száguldozás, a munkahelyi döntésekbe való beleszólás, vagy éppen az egyenló jogok kivívása volt?

2005 őszén bebizonyosodott, hogy nem lehet fenntartani a társadalmi fejlődést, nem lehet javítani a gazdasági versenyképességet akkor, ha a társadalmi kohézió nem biztosított. Egyértelmúvé vált, hogy nemcsak az érintett hátrányos helyzetú kisebbségi 
csoport érdekében fontos a szociális problémák kezelése, a perifériára szorultak életfeltételeinek a javítása, társadalmi kirekesztődésük megakadályozása, vagy nagyobb gond fordítása a deviáns magatartások megelözésére, hanem a többségi társadalom biztonságának, életminôségének megốrzése érdekében is. A társadalmi kohézió fontosságáról természetesen korábban is sok szó esett. A kohézió erốsítése az Európai Unió dokumentumaiban hivatalos célkitûzésként szerepel. Ám lehetett úgy is vélekedni, hogy a kohézió erôsítése a gazdasági versenyképesség javításához képest mégis csak periferikus cél, melynek eléréséhez a feltételeket majd a versenyképesség javulása teremti meg. Sốt, egyesek úgy vélték, hogy a társadalmi kohézióra - és a fenntarthatóságra - fordított figyelem és pénz rontja az alapcél elérésének, azaz a versenyképesség javításának a feltételeit.

Ezek az elképzelések 2005 ôszén tarthatatlanná váltak. Mindenkinek be kellett látnia, hogy az Európai Unió által megfogalmazott alapcél elérésének, azaz a legversenyképesebb tudásalapú régióvá válásnak nélkülözhetetlen elófeltétele a társadalmi kohézió fenntartása és megerősítése. A gazdasági és társadalmi fejlődéshez, az életminôség javulásához biztosítani kell a társadalmi összetartozást. Az összetartozásnak ki kell terjednie a társadalom valamennyi csoportjára, a legkülönbözóbb szociális, kulturális, etnikai csoportokra. A kohézió feltétele, hogy a különbözó csoportok közötti egyenlốtlenségek ne legyenek olyan mértéküek, hogy valamely csoport kirekesztődésével, a társadalom többségétól történó végleges leszakadásának veszélyével járhassanak, és tagjaikban a teljes reménytelenség érzését kelthessék.

A társadalmi kohéziót az emberi kapcsolatok biztosítják. A kapcsolatok, melyek társadalmi tókeként funkcionálnak. A társadalmi integráció azt feltételezi, hogy minden csoport úgy lehet a társadalom egyenrangú része, hogy közben megórizheti saját pozitív identitását. Mindez a fenntartható fejlődésnek is fontos kritériuma. Magyarországon a fenntarthatóság követelményét sajátos módon sokan összetévesztik, azonosítják a környezetvédelemmel, a környezeti biztonság kritériumával. Valójában a fejlődés fenntarthatóságának az is feltétele, hogy a szociális feszültségek ne váljanak elviselhetetlen méretûvé, a társadalmi konfliktusok ne éleződjenek ki oly mértékig, mely a társadalom biztonságosságát és ezáltal a fejlôdés fenntarthatóságát veszélyeztessék.

A szociális problémák kezelése ma már nem értelmezhetố emberbaráti, jótékonysági ügyként. Tudomásul kell venni, hogy a gazdaság sikerességének az előfeltétele, nem csak a biztonsági szempontok miatt. Figyelni érdemes Európa elöregedó társadalmainak mind vészesebbé váló munkaerốgondjaira, amelyek szintén nélkülözhetetlenné teszik a ma szociális támogatásokból élố munkaképes csoportoknak a felkészítését a sikeres munkaerô-piaci megjelenésre, a foglalkoztatásra. Szükségessé teszi továbbá a hiányzó munkaerố más szociokulturális környezetból történô pótlását, ami várhatóan újabb integrációs problémákat vet fel. Végezetül a gazdaságnak a vásárlóerôvvel rendelkezó fogyasztókért folytatott küzdelme is feltétlenül szükségessé teszi a ma leszakadóban lévő, kirekesztốdött társadalmi csoportok integrálását a társadalomba, és ezáltal a fizetôképes keresletet bóvítő fogyasztói körbe.

Érzékelhettük és érzékelhetjük továbbá azt is, hogy a felmerülő problémák nemcsak a társadalom szükségszerú vertikális tagozódásából fakadnak, nemcsak szociális jellegú gondok várnak megoldásra, hanem ezek gyakran etnikai, nemzetiségi színezetet is öltenek, kisebbségi vonatkozásaik is vannak. 


\section{Szociális hátrányok és etnikai különbségek}

Politikai, jogi és szociológiai szempontból egyaránt vitatható és vitatott is, hogy a Franciaországban 2005 ószén lezajlott zavargások értelmezhetôk-e kisebbségi ügyként. A helyzetet bonyolírja, hogy ma már nemcsak a Nyugat-Európában eredetileg kialakult két álláspont áll egymással szemben, hanem az EU bơvülésével új gondok és álláspontok kerültek napirendre. A hagyományosan kialakult egyik álláspont szerint az egykor más földrészekról bevándoroltak leszármazottjai kisebbségieknek nem tekinthetô francia állampolgárok, függetlenül az óket a többségtól mégiscsak megkülönböztetố bốrszínüktól és más, szembetűnően különböző külső adottságaiktól. A másik álláspont szerint az állampolgári jogok teljes körének és az egyenlő bánásmódnak a garantálása mellett kisebbséginek lehet és kell tekinteni mindazokat a csoportokat, amelyek a többségtól eltérố adottságokkal bírnak, illetve eltérô szociokulturális körülmények között élnek. A kisebbség fogalmának ilyen tág definíciója alapján nem lehet leszúkíteni a kisebbségi létet a hátrányos helyzetre, továbbá nem lehet sem az egyéni döntésektốl független adottságokhoz, sem a kifejezetten egyéni választáson alapuló helyzetekhez kötni a kisebbséghez tartozást. A társadalmi helyzet szempontjából releváns bármely sajátosság mentén a társadalom a többséghez tartozókra és a kisebbségiekre osztható fel. Ha ezt a megközelítést elfogadjuk, akkor a kisebbséghez tartozóként történő besorolás nem értéktartalmú és semmiképpen sem pejoratív minôsítés.

Ebben az értelemben az afrikai bevándorlók leszármazottai külsố megjelenésük közös sajátosságai miatt eleve egy kisebbséghez tartozónak tekinthetók. Kisebbségiként definiálhatók továbbá szociális hátrányaik hasonlósága miatt, valamint megốrzött kulturális közösségük miatt. A kulturális kisebbséghez tartozás alapozódhat a bevándorlói létból fakadó közös életértelmezésre, életmintákra, vagy éppen a külvárosi lakótelepi ifjúsági szubkultúra közös elemeire.

Annak a megítéléséhez, hogy valami kisebbségi ügyként kezelhetô-e, újabb szempontot vet fel a nemzeti vagy etnikai kisebbség meghatározásának Közép- és Kelet-Európában elfogadott megközelítési módja. Az újonnan csatlakozott EU-tagállamokban a kisebbségi kérdés mindenekelốtt úgy jelenik meg, mint az adott állam területén élố, de valamely szomszédos ország többségi nemzetéhez tartozó nemzetiségek ügye. Ezekben az országokban általános az a szemlélet, amit a magyar kisebbségi törvény úgy fogalmaz meg, hogy nemzeti, etnikai kisebbségnek a Magyarországon legalább 100 éve honos nemzeti, etnikai kisebbségek tekinthetók. Ezekben az országokban tehát a legutóbbi idókben vagy jelenleg bevándorlók nem minôsülnek nemzeti, etnikai kisebbségnek, legalábbis a hivatalos értelmezés szerint nem. Könnyen megjósolható persze, hogy az EU-hoz történő csatlakozás, a bevándorlók számának jelentôs megnövekedése itt is elốtérbe helyezi a Nyugat-Európában meglévố problémákat, és ez várhatóan elvezet a kisebbségekkel kapcsolatos szemlélet, sốt, esetleg a szabályozások megváltozásához is.

Ha most keresünk analógiát a francia események és a magyar társadalomban aktuális problémák között, akkor leginkább a cigányság helyzetére gondolhatunk. Egyrészt a Magyarországon élő nemzeti, etnikai kisebbségek közül a cigányság az a csoport, amely külső megjelenésében leginkább eltér a többségi társadalomtól, és ez a szabad identitásválasztás jogának elismerése mellett is azzal a következménnyel jár, hogy a 
többségi társadalom tagjai a kategorizáció útján történó megismerés során „más” csoporthoz tartozónak tekintik óket. Ez a fajta besorolás a „más” kategóriájába nem azonos az elóítéletességgel, és még kevésbé a diszkriminációval.

Az asszimilálódott, szociokulturálisan a többséggel azonosult és cigány identitással nem rendelkezóket a többségi társadalomhoz tartozók külsejük „cigányossága” ellenére sem tekintik „,cigány kisebbséginek”. A Magyarországon élő cigányság jelentôs része azáltal alkot egy nagyon sajátos kisebbséget, hogy az eltérő etnikai származáson kívül a halmozottan hátrányos szociális helyzet is összeköti óket. Magyarországon a többségi társadalom tagjainak zöme a „cigány kisebbség” megjelölés alatt nem az etnikai származásuk közössége alapján egy populációhoz sorolható egyéneket érti, hanem a halmozottan hátrányos helyzetú cigányokat, akik közé nem ritkán besorolnak származásuk szerint valójában nem cigány, de az adott szociokulturális közösséghez tartozó egyéneket is.

Az asszimilálódott, illetve integrálódott cigányságról szinte semmit nem tudunk, mert óket környezetük nem tekinti cigánynak, és a cigány megjelöléshez kapcsolódó negatív sztereotípiák miatt nagy részük nem hangoztatja cigány voltát. A szociológiai vizsgálatokat végzố kutatók szintén nem vesznek tudomást róluk, mivel - a szociológusok által amúgy mélyen elítélt előítéleteket átvéve - ók is szinte kivétel nélkül a halmozottan hátrányos helyzetű, nem integrálódott cigányság körében kutatnak. A ,cigány kisebbségként” definiált körben a szociális problémák vészesen halmozódnak. Egyre aggasztóbb méreteket ölt a tartós munkanélküliség, ami szorosan összefügg az alacsony iskolázottsággal, a szakképzettség hiányával. Jellemzó vonások a rossz lakáskörülmények, a szegénység, a gyakori betegségek és a rövidebb várható élettartam.

Ezekben a családokban szinte automatikusan örökítődik át az alacsony társadalmi státus a gyermekekre, minimális az esélye nemcsak az intragenerációs, hanem az intergenerációs mobilitásnak is: nemcsak arra nincs esély, hogy a szülók saját életükön változtassanak és magasabb státusba kerüljenek, hanem arra is nagyon kevés az esély, hogy gyermekeik a társadalmi egyenlôtlenségek rendszerében magasabb helyre kerülhetnek. Sorsuk rendszerint már az általános iskola első osztályában megpecsételődik azáltal, hogy otthonról hozott szociokulturális sajátosságaikat az iskola egyéni alkalmatlanságként, nem ritkán fogyatékosságként értelmezi és rossz iskolai teljesítményként minősíti. Iskolai kudarcaik miatt ók sem jutnak aktív gazdasági szerephez, hanem a szociális ellátásokra rászorulók körét bơvítik. Figyelemmel arra a tényre, hogy ebben a társadalmi csoportban általában gyakori a magas gyermekszám, ez a helyzet folyamatosan bővítetten újratermelôdik.

Megállapíthatjuk tehát, hogy a társadalmi kohéziót legsúlyosabban veszélyeztetố probléma Nyugat-Európában a bevándorlók, illetve leszármazottaik társadalmi integrációjának elmaradása, az etnikai különbözôség összekapcsolódása a halmozottan hátrányos szociális helyzettel. Ugyanakkor Magyarországon a társadalmi kohéziót leginkább fenyegetô veszély a halmozottan hátrányos szociális helyzetú cigányság leszakadásának, társadalmi kirekesztődésének a veszélye. Bár Magyarországon a franciaországi eseményekhez hasonló súlyosságú rendbontásokra, összetúzésekre nem került sor, a felhalmozódó feszültség jelei idốról időre megnyilvánulnak.

Mi a megoldás? Ez a kérdés itt is, ott is felvetôdik. És úgy túnik, hogy a világ modern ipari társadalmai nem takargathatják már túl soká meztelenségüket, vagyis azt, 
hogy nem tudtak, és nem tudnak mit kezdeni az etnikai és szociális problémák kibogozhatatlanul egymásba gabalyodott tömegével, ami egyre fojtogatóbban szorul a nyakuk köré. Nem tartható már sokáig fenn az önmagukról kialakított és őrzött kép, mely szerint az ô történelmi útjuk a fejlődés csúcsát jelenti, és mindenki számára kötelezô modell. Ezt a felvilágosodás kora óta dédelgetett álmot rég megkérdôjelezik a multikulturalizmus hirdetôii, akik a kultúrák egyenrangúságának tételéból kiindulva a sok egymástól eltérô kultúra sajátosságainak megốrzésében, békés egymás mellett élésében vélik felfedezni az üdvözítô megoldást. Az ő elképzeléseik szerint a sajátos identitásukat megôrző etnikai, nemzetiségi, szociális, kulturális és vallási csoportok együtt élése asszimiláció, vagy akár integráció nélkül is megoldhatja a mai feszültségeket.

Megint mások a globalizáció kedvezô hatásaiban bízva várták a kibékíthetetlennek tûnő feszültségek feloldását, a konfliktusok békés kezelését, a robbanásveszélyes területi, gazdasági, szociális és egyéb egyenlőtlenségek tûrhetôvé mérséklődését. A második évezred utolsó évtizedének és a harmadik évezred elsố fél évtizedének eseményei eddig sajnálatos módon nem igazolták, inkább cáfolták mind a multikulturalizmus, mind a globalizáció híveinek reményeit.

Az államszocialista birodalmak szétesését követô etnikai alapú véres háborúk, a 2002. szeptember 11-én történt terrorcselekmények a közel-keleti válság elhúzódásával és sok más eseménnyel együtt azt bizonyítják, hogy még hosszú ideig reálisan számolnunk kell az eltérő szociális és kulturális helyzetú csoportok, és mindenekelốtt az eltérô etnikai, nemzetiségi, vallási közösségekhez tartozók közötti konfliktusokkal.

Úgy tûnik, hogy a „világfaluban” közeli kapcsolatba kerülô, naponta érintkezô, egymás szomszédságában lakó, egy munkahelyen dolgozó, gyermekeiket egy iskolába járató, de eltérô szociokulturális hátterú emberekre egyelőre nem az egymás megértése iránti vágy, nem az elfogadás, nem a kölcsönösen előnyös megoldások keresése a jellemzô. Sốt, ellenkezóleg: a saját csoport és az idegen csoport közötti különbözôség eltúlozása, a saját csoporthoz tartozók pozitívumainak és az idegen csoporthoz tartozók negatívumainak irracionális mértékúvé növelése tekinthetố jellemzőnek. A saját érdekek, törekvések érvényesítését csak a másik ellenében, a másik legyốzésével vélik megvalósíthatónak. A saját gondok és nehézségek okát a valós tények helyett a másik csoport, az „idegenek” cselekedeteivel, vagy akár pusztán a jelenlétével hozzák összefüggésbe, s ezzel beindítják a kiszámíthatatlan következményekkel járó bûnbakképzési mechanizmust.

A globalizáció bizonyos külsődlegességeket, fogyasztási szokásokat, divatokat egységesíteni tudott akár világméretekben is, de a lényegi különbözóségeket nem szüntette meg, sốt inkább felerôsítette. A szegénység, a különféle kívánatos javak hiánya, a jólléttól való megfosztottság sokakban éppen a globalizáció és az azt közvetítố médiumok révén tudatosult. A megfosztottság, a kirekesztettség élménye azáltal vált igazán elviselhetetlenné, hogy a tömegkommunikációs eszközökból áradó információk révén, vagy akár a mindennapi személyes találkozások alkalmával naponta szembesülni kellett, illetve kell a világ napos oldalán élók gazdagságával, jólétével, valós vagy látszólagos elégedettségével.

A nyugati világ, az északi félteke segélyezési akciói, anyagi támogatása, saját civilizációs mintáinak terjesztése nem hozta meg a várt hatást, sốt újabb feszültségeket gerjesztett - ahogy a magyarországi cigányság helyzetét sem tudta érdemben megváltoz- 
tatni sem az államszocializmusban biztosított teljes foglalkoztatottság, sem a mai romaprogramokra fordított költségvetési keret, az anyagi támogatás.

A kudarcok belátásán túl mit lehet tenni? Fel kell figyelni arra az alapvető változásra, melyet az információs társadalom kialakulása eredményez, és amely egyszerre jelent új veszélyeket és új esélyeket a társadalmi kohézió, a szociális feszültségek enyhítése, a kisebbségi konfliktusok megelôzése szempontjából is. Ma több szó esik a veszélyekról, a kialakuló digitális szakadékról. A halmozottan hátrányos helyzetúek számára a teljes kirekesztődés, a megsemmisülés rémét vetíti eloóre az a szemlélet, mely szerint azok, akik nincsenek rajta a világhálón, akik kimaradnak az információs társadalom nyújtotta lehetốségekból, a mai világban gyakorlatilag nem léteznek. Ha ebból az aspektusból vizsgáljuk a francia városokban kitört zavargásokat, akkor úgy is értelmezhetjük azokat, hogy a létükben megkérdójelezett tömegek drasztikus módon jelentkeztek be, és így adtak életjelet magukról.

\section{Az információs társadalom hatása az egyenlőtlenségi rendszerre}

Sok szó esik napjainkban arról, hogy világméretû korszakváltás időszakát éljük. Most váltja fel a modern ipari társadalom korát a tudásalapú információs társadalom kora. Ennek a változásnak a jelentôsége csak ahhoz hasonlítható, amikor a premodern agrártársadalmat felváltotta a modern ipari társadalom. Az első változást az ipari forradalom idézte elő, melynek jelképe a gőzgép volt. A jelenlegi átalakulást az információs forradalom okozza, melynek jelképe az internet. Tudjuk, hogy a modern ipari társadalom szinte minden vonatkozásában különbözik a modern kor elốtti agrártársadalomtól. Ugyanígy a tudásalapú információs társadalom szinte mindenben más, mint az ipari társadalom. A különbség lényege ugyanúgy nem köthető csupán az internethez, miként a modern kor lényege sem a gôzgép.

A korszakváltások során megváltozik a gazdaság szerkezete, az emberi érintkezési viszonyok jellege és a fejlesztési erôforrások mibenléte. A történelem korai idôszakában a meghatározó gazdasági ágazat a mezőgazdaság volt. Az emberek közötti kapcsolatok a természet adta közösségekben jöttek létre. Ezekben a közösségekben ugyanazok az emberek alkották a rokonságot, a szomszédságot, a munkahelyi, a vallási és a szabadidốs közösséget. Az egyén nagy valószínúséggel egész életét abban a közösségben élte le, amelybe beleszületett. A közösség minden vonatkozásban meghatározta az egyén életét, viselkedését. A modern ipari társadalmakban a meghatározó gazdasági ágazattá az ipar vált. Az emberi kapcsolatok tipikusan mesterséges csoportokban szerveződnek. Ilyen mesterséges szerveződések a gyárak, a hivatalok, az ipari üzemek, a pártok. Megváltozott a lakókörnyezet. Amíg a premodern társadalmakban az emberek túlnyomó többsége falvakban élt, a modern kor emberei városokban élnek. Az agrártársadalomban az elöre pontosan meghatározott tartalmú személyes emberi kapcsolatok domináltak. Az ipari társadalmak jellemzóje a tömeglét, a szürke egyformaság, a másokhoz való igazodás feltétlen kényszere, a személyes jelleg leépülése. A premodern agrártársadalmak legfóbb fejlesztési erôforrása az emberek fizikai ereje, az állatok fizikai ereje, vala- 
mint a föld volt. Ezeknek az erôforrásoknak a bőséges vagy szúkös voltától függött egy-egy térség, társadalmi csoport vagy éppen család fejlettségi szintje.

A modern ipari társadalmakban a fejlődés meghatározó erőforrásaivá a befektethetố materiális tốke és a gépek váltak. A korábban az egyenlőtlenségi rendszerben alul elhelyezkedók hirtelen új esélyeket kaptak, mert többé nem az igavonó állatok mennyisége, a fizikai munkára fogható rabszolgák vagy jobbágyok száma, nem a föld termóképessége határozta meg a fejlődést. A korábban elmaradottak, hátrányos helyzetúek hirtelen előnyös pozícióba kerülhettek, ha idóben gépesítették gazdaságukat, ha a rendelkezésükre álló anyagiakat idóben elkezdték tókeként forgatni. Természetesen voltak olyanok is, akik elmulasztottak idóben váltani, nem ismerték fel a változás irányát. Ha egy térség, egy társadalmi csoport eleve hátrányos pozícióból indult és lekéste az új korszak startját, nem ismerte fel az új erôforrások jelentôségét, akkor könnyen végérvényesen leszakadhatott, eltúnhetett a történelem porondjáról.

A most kialakuló tudásalapú információs társadalomban a gazdaság meghatározó ágazatává a szolgáltatás válik. Természetesen - ahogy az ipari társadalomban is fennmaradt a mezógazdaság - az információs társadalomban is szükség van mezốgazdaságra és iparra, csak az arányok tolódnak el. A szolgáltatások hagyományos formái, a kereskedelem, a vendéglátás, az idegenforgalom mellett elótérbe kerülnek azok a humán szolgáltatások, amelyek az emberi élet minóségét hivatottak jobbá tenni. Ezek között az egészségfejlesztés körébe sorolhatók az egészséges táplálkozást és a környezet egészségesebbé válását biztosító szolgáltatások, a szabadidős sportok, a rekreációs tevékenységek, valamint a testi, lelki egészség megôrzését, karbantartását és helyreállítását célzó legkülönbözóbb egyéb szolgáltatások.

A tudás, az információk elérhetôségének biztosítására az oktatás hagyományos formái mellett számtalan új szolgáltatás alakul ki, a képességek felismerésére irányuló, a pályaválasztást orientáló szolgáltatásoktól kezdve az élethosszig tartó tanulás legkülönbözóbb formáin át az információk, a digitalizált tudástartalmak elérhetőségét, szelektálását és hasznosítását segítố szolgáltatásokig. A tágan értelmezett kultúra területéhez tartozó pénzügyi, technikai, tömegkommunikációs, szabadidôs és közigazgatási szolgáltatások mellett a búnözést és más deviáns magatartásokat megelőzni hivatott szolgáltatások, a társadalmi kohézió erôsítésére, a közösségek fejlesztésére irányuló szolgáltatások, valamint a különbözố társadalmi csoportok békés egymás mellett élését, a konfliktusok feloldását támogató szolgáltatások rendkívül széles köre van kibontakozóban. Ezek a szolgáltatások speciális szakértelmet, kompetenciákat igényelnek, a rohamosan növekvő társadalmi szükségletekre figyelemmel nagyon sok ember foglalkoztatását biztosíthatják, és többségükben piaci alapon, vállalkozások formájában nyereségesen valósíthatók meg.

Az emberi kapcsolatok tipikus formájává a hálózat válik. A hálózat az egyenrangú partnerek közötti horizontális kapcsolatrendszer, mely a bizalmon alapul, és amely egymás megértésére, valamint a megegyezésre irányul. A modern ipari társadalmak tömegjellegével, egyformaságával szemben felértékelődik az egyediség, a specialitás, a személyesség. Az agrártársadalomban ezzel szemben egy településnek, egy társadalmi csoportnak, egy családnak és minden egyes egyénnek a neki eleve kijelölt feladatok ellátásával kellett szerepét betöltenie. A modern ipari társadalomban a futószalagon folyó termelés mintájára mindig mindent ugyanúgy kell tenni, ahogy a többiek teszik, azt 
kell fogyasztani, amit mások fogyasztanak, úgy kell viselkedni, ahogy azt a külső elvárások, divatok diktálják. Minden és mindenki egyforma, pótolható, helyettesíthetô.

A tudásalapú társadalomban felértékelődik az egyediség. Az az érdekes, az a fontos, ami csak azon az egy helyen látható, amit csak az a szolgáltató tud nyújtani, amire csak az az egyetlen ember képes. Mindenki megmutathatja egyedi, megismételhetetlen, pótolhatatlan voltát, azokat a sajátosságait, amelyekkel kizárólag ô rendelkezik. A tudásalapú információs társadalom meghatározó jelentőségú fejlesztési erőforrásai a kulturális tốke és a társadalmi tóke.

\section{Új fejlesztési erőforrások, az információ és a bizalom felértékelődése}

A kulturális tóke a tudás, az emberi képességek, készségek, kompetenciák, a mindennapi élet mintázataként értelmezett kultúra. A társadalmi tóke az emberi kapcsolatok hálózata, mindenekelő́tt a bizalom. A kulturális tóke és a társadalmi tóke egyenértékú a materiális tốkével. Mindhárom tókeféleség akkumulálható és konvertálható, azaz kölcsönösen átválthatók egymásra.

A modern ipari társadalom mércéjével mérve minél hátrányosabb helyzetú egy térség, egy társadalmi csoport, egy család, vagy éppen egy egyén, minél szúkösebben áll rendelkezésére a materiális tóke, annál nagyobb szüksége van a változás idóben történó felismerésére és saját javára fordítására. A most zajló korszakváltás - éppúgy, mint annak idején az agrártársadalomról az ipari társadalomra történó áttérés - újrarendezi a társadalmi egyenlótlenségeket, és ezáltal esélyt ad a hátrányok gyors leküzdésére és kedvezố helyzet kivívására. Ám ha az előző korszak hátrányaihoz újabb hátrányok kapcsolódnak, akkor a leszakadás, a fejlődésból történô teljes kirekesztốdés reális veszéllyé válik.

A társadalmi kohézió erôsítése a kapcsolatok erôsítését követeli meg. A társadalmi kapcsolatok szervezôdhetnek vertikálisan és horizontálisan. A hálózati típusú kapcsolatok horizontális jellegúek, egyenrangú felek bizalomalapú, megegyezésre és együttmúködésre irányuló kapcsolatai. A hagyományosan szerveződő horizontális kapcsolatok mellett az infokommunikációs eszközök kiváló lehetôséget biztosítanak a bizalmon alapuló kapcsolatok erôsítésére. Az információs társadalomban új technikai és technológiai lehetőségek használhatók fel a kapcsolati hálózatok bővítésére, erôsítésére és hasznosítására.

Az új technikák és technológiák megjelenésével, a világháló és más infokommunikációs eszközök révén olyan társadalmi átalakulás zajlik körülöttünk, ami együtt jár a társadalmi egyenlốtlenségek újra rendeződésével. Fennáll annak a veszélye, hogy a korábbi kedvezôtlen strukturális pozíciók újabb hátrányokkal kapcsolódnak össze, és ez tovább súlyosbítja a már ma is depriváltak helyzetét. Ha a sokat emlegetett digitális szakadék a mai halmozottan hátrányos helyzetúek csoportja és a társadalom többsége közé ékelốdik, akkor megnő a végleges leszakadás, a teljes kirekesztốdés valószínúsége.

Az információs társadalom azonban esélyt nyújt a korábbi hátrányok gyors kompenzálására és a korábbi kedvezốtlen státus jóval kedvezóbbé tételére. A kedvezó irányú változásokhoz elôször is fel kell ismerni az új lehetốségeket, el kell kötelezôdni a 
megújulás mellett. Tudatosítani kell az új fejlesztési eróforrásokat, ki kell alakítani akkumulálásuk, hasznosításuk és konvertálásuk mechanizmusait. Könnyen lehet, hogy azok a térségek, települések és társadalmi csoportok, amelyek a hagyományos erôforrásokban szúkölködnek, mert kevés a befektethetố anyagi tókéjük, alacsony az egy fốre jutó GDP-jük, továbbá nincs magas jövedelmet termelő és megfelelő foglalkoztatást biztosító iparuk, mezôgazdaságuk, kedvezóbb helyzetben vannak az új erôforrások szempontjából. Lehet, hogy bővebben áll rendelkezésükre kulturális és társadalmi tốke, vagy azért, mert megórizték, vagy pedig idóben nekiláttak a felhalmozásának.

Rendkívül fontos feladat, hogy szociológiai kutatások révén minél elóbb megtörténjen a rendelkezésre álló erôforrások felmérése, a releváns információk rögzítése és a hasznosítási lehetôségek tudatosítása, valamint a fejlesztési programok kidolgozása és megvalósítása. A már elvégzett kutatások eredményei biztatóak. Úgy tûnik, hogy a most felértékelődő tényezők egyik legfontosabbika, az egymás iránti bizalom sokkal inkább megôrződött az egyébként hátrányosabb helyzetű csoportokban és lokális közösségekben, településeken, kistérségekben. Különösen fontos ez annak tudatában, hogy például Fukuyama, a Bizalom címú mú szerzốje szerint a volt államszocialista rendszerek legnagyobb deficitje éppen a bizalom területén mutatkozik. Fukuyama részletes gazdasági elemzésekkel támasztja alá, hogy a gazdasági teljesítóképesség legfóbb meghatározójává a bizalom vált. Különös jelentôséggel bír tehát, hogy a tudásalapú információs társadalom fejlesztése a hátrányos helyzetú területeken és csoportokban megvalósuljon.

Tudjuk, hogy ma Magyarországon a korszerú infokommunikációs eszközökhöz való hozzáférés és ezáltal az információkhoz, a korszerư tudáshoz való hozzájutás biztosítása a legfontosabb cél. Ennek a célnak az eléréséhez három feladat megvalósítására van egyidejû́leg szükség. Az egyik az internetes hálózat kiépítése és a rácsatlakozást biztosító eszközök további terjedése, vagyis a technikai feltételek megteremtése, az eszközök biztosítása. A másik feladat a digitális írástudás általánossá tétele, a harmadik pedig az infokommunikációs eszközök, különösen az internet használatára való motiváltság erôsítése. Ma Magyarországon az internethasználat további elterjedésének egyik legnagyobb akadálya az, hogy az emberek jelentôs része nem ismeri fel a digitális írástudás és az internethasználat elônyeit, $s$ ezért nem is törekszik a szükséges készségek elsajátítására, illetve a rákapcsolódásra és a használatra. Ezek a legsürgetôbb feladatok és a legnagyobb esélyt nyújtó feltételek a leghátrányosabb helyzetû́ek körében is.

\section{Az információs társadalom lehetőségeinek gyakorlati hasznosításai}

Mindezek felismerése alapján indult el három évvel ezelőtt a „Digitális Középiskola" modellkísérlete Borsod-Abaúj-Zemplén megyében. A kísérlet kezdeményezôje az IHM államtitkára, a Miskolci Egyetem Szociológia Tanszékének professzora, Csepeli György volt. A képzés elindítására a Miskolci Egyetem, a Miskolcon múködő Földes Ferenc Gimnázium és egy miskolci székhelyú informatikai vállalkozás, az Innocenter 
Kft. kötött konzorciumi megállapodást. A képzést a megye leghátrányosabb helyzetú településein élő́, leghátrányosabb helyzetú emberek számára indították. Az első évfolyam tanulói szinte kizárólag romák, de a második és a harmadik évben indított évfolyamokon is magas az arányuk. A tanulók jelentôs része munkanélküli, sokan élnek rossz szociális körülmények között. A Digitális Középiskolának összesen 517 tanulója van.

A gimnáziumi tananyagot a Földes Ferenc Gimnázium tanárai digitalizálták, ôk alakították ki az online számonkérések és kapcsolattartási formák módszereit, és ók valósítják meg a konkrét képzést. A tanulóknak nem kell a megyeszékhelyre vagy a lakóhelyüktól távol esố más iskolába bejárniuk, ami gyakorlatilag számukra leküzdhetetlen akadályát képezné a tudás megszerzésének, a kulturális tốke akkumulálásának. A megye 11 településén alakították ki azokat az oktatási helyeket, ahol korszerú gépek teszik elérhetơvé a tanulók számára a digitalizált tananyagokat. Ezeken az úgynevezett „információs pontokon" mód van arra is, hogy a diákok személyes kapcsolatba kerüljenek a tanulásukat közvetlenül segítố tanárokkal. A Miskolci Egyetem szociológia szakos hallgatói folyamatosan nyomon követik a Digitális Középiskola tanulóinak előrehaladását, és erôsítik motivációjukat.

Ez a képzési forma tehát az információs társadalom nyújtotta technikai lehetốségekre épít, felhasználja az internetet és a digitalizált tudástartalmakat, feltételezi és hasznosítja a digitális írástudást. A képzés rendkívül jó hatékonysággal múködik. A lemorzsolódási arány nem haladja meg a felnóttek hagyományos esti vagy levelezố tagozatos képzésében szokásos lemorzsolódási arányt. Ez a képzési forma az eddigi tapasztalatok alapján alkalmasnak túnik a hátrányos társadalmi helyzetû csoportok sikeres képzésére.

A modern társadalmakban Bourdieu és mások kutatásai szerint az oktatási rendszer alapvetô funkciója a társadalmi egyenlôtlenségek újratermelése és legitimálása. A hátrányos helyzetû́ csoportok, és különösen a cigány tanulók oktatása során tapasztalt gyakori kudarcok Magyarországon is annak a jelei, hogy az oktatási rendszer nem esélyeket biztosít a társadalmi felemelkedésre, hanem a szülók társadalmi helyzetét örökíti át szinte automatikusan gyermekeikre. Ez a tényleges funkciója az iskolának, és ezt nem érdemes diszfunkcióként értelmezni. Kezdetben Bourdieu is úgy vélte, hogy azok az iskolák, amelyek nem adnak lehetôséget a gyermekek számára a szüleikénél magasabb státus elérésére, diszfunkcionálisan múködnek. Sok-sok empirikus kutatás eredményeinek megismerése után ismerte föl, hogy valójában éppen az egyenlőtlenségek generációk közötti átörökítése a normálfunkció. Ebból az elméleti keretból szemlélve teljesen terméketlen és gyakorlatilag teljesen haszontalan az a vita, mely a cigány tanulók szegregált vagy integrált oktatásáról szól, mert a tanulók iskolai elómenetelét mind a szegregált, mind az integrált oktatás során a legdöntóbb módon szüleik társadalmi státusa határozza meg.

A Digitális Középiskola sajátos, újszerú körülményei között kevéssé hatnak az egyenlốtlenségeket konzerváló, átörökítố mechanizmusok. Ez az oktatási forma alkalmasnak tûnik a valódi esélyteremtésre, a tudás tókeként történố akkumulálására. Figyelemmel azonban a tanulók hátrányos helyzetére, rendkívül fontos az oktatási program kiegészítése szociális támogatásokkal. A digitális írástudás ezen a téren is jól hasznosítható, mert alkalmat ad egyrészt a tájékozódásra a szociális támogatási for- 
mákról, másrészt - az e-közigazgatás terjedése révén - a szociális ügyintézésre is. A munkanélküliek magas aránya szükségessé teszi a gimnáziumi képzés kiegészítését piacképes szakképzéssel, és célszerú speciális foglalkoztatási program kialakítását. A képzés a tanulók többségét alkalmassá teszi olyan helyi „kulcsember” funkciójának betöltésére, ami részben vezetôii, részben segítô-közvetítố mentori, illetve mediátori feladatok ellátását jelentheti. Új típusú szolgáltatások jelenhetnek meg a digitális középiskolások lakóhelyein, közösségeiben, amelyek megsokszorozhatják a képzések kedvező hatásait.

Az ilyen feladatok ellátása, illetve új szolgáltatások múködtetése iránti igény már eddig is körvonalazódott. A hagyományos szociális asszisztensi feladatokon kívül ilyen feladatkörrel jár az egészségfejlesztő mentálhigiénikus, a búnmegelőzési szakember, a közösségszervezô, valamint az infokommunikációs segítô funkciójának betöltése. A hátrányos helyzetú térségekben és a hátrányos helyzetú csoportokban lesz igazán fontos az „információstársadalom-mentor” képesítésú fiatalok alkalmazása. Az erre az új szakmára felkészítő oktatás most kezdődik el Magyarországon.

A tapasztalatok szerint a számítógépek és az internet használatának lehetôségei jó közösségszervezési alkalmakat jelentenek, és jó lehetốséget biztosítanak a társadalmi kohézió erôsítésére. Búnmegelôzési célú programok monitorozása során tûnt fel az a jelenség, hogy a csellengő fiatalok bevonására a leghatékonyabb módszer ma olyan helyek létesítése, ahol a fiatalok számára biztosítják a számítógép használatát és az ingyenes hozzáférést az internethez. Ha alkalmuk van ennek a szolgáltatásnak a rendszeres igénybevételére, akkor az ott folyó szociális és kulturális programokba is nagy valószínúséggel önként bekapcsolódnak. Elindul a közösségfejlődés, ami már nem valamely deviánsnak minósülő tevékenység köré szervezôdik.

A Miskolci Egyetem egy 800 lakosú Borsod-Abaúj-Zemplén megyei községben, Sajópálfalán 5 évvel ezelốtt Társadalomkutató Kihelyezett Központot hozott létre, melynek keretében a faluban éló emberek számára is megnyitották az egyetem ott múködő́,információs pontját”. A lehetőséggel nemcsak a fiatalok, hanem az idôsebb korosztályhoz tartozók is szívesen éltek és élnek ma is. A központban elindított Egyetemi órák Sajópálfalán címú sorozatot már a regionális televízió is sugározza havonta egy alkalommal, 50 perces adás keretében. Az egyetemi oktatók elôadásaikban a régió alapvető gondjaival foglalkoznak, és megkísérlik ilyen módon is bizonyítani, hogy a tudás, az információ a gyakorlatban jól hasznosítható erőforrás, konvertálható tôke. Az előadások szövege és a kapcsolódó anyagok elérhetôk az interneten is.

A Miskolci Egyetem tervezi egy olyan Regionális Multimédia Központ létesítését, amely az egyetem kutatóinak informatikai innovációit a gyakorlatban hasznosító digitalizált televízió- és rádiómúsorok készítését biztosítaná. Ezek a músorok tartalmukban erốteljesen támaszkodnának az egyetemen felhalmozódott és naponta újratermelődố tudásra. Ennek a Központnak a részét képezné az a Regionális Digitális Adattár, amely EU-konform regionális statisztikai rendszer kialakításával, társadalomtudományi kutatásokkal megalapozottan gyújtené, rendszerezné, digitalizálná és a világhálón hozzáférhetôvé tenné a régió kistérségeire, településeire vonatkozó releváns információkat.

Ahhoz, hogy a ma hátrányos helyzetúnek minôsüloó régiók, települések, társadalmi csoportok ne rekesztődjenek ki végérvényesen a társadalom fejlôdéséból és ne ve- 
szélyeztessék a többség fejlődését, fel kell használnunk az információs társadalom nyújtotta új lehetôségeket a társadalmi kohézió erôsítésében is.

A modern ipari társadalmak fejlődésének mércéje Luhmann rendszerelmélete szerint az autonóm alrendszerek elkülönülésén alapuló hatékonyság. Habermas felhívta a figyelmet arra, hogy a hatékony múködésért túl nagy árat kell fizetni. Az egyik ár az életvilág gyarmatosítása, a személyes kapcsolatok széthullása. A másik ár a devianciák megnövekedése. Aki nem felel meg a hatékonyságot biztosító alrendszerek szigorú szelekciós mechanizmusának, az deviánsnak minősül, leíródik, selejtként kezelik. Gyógyítják, büntetik, gondoskodnak róla... Az információs társadalom korában azonban az emberi kapcsolatok felértékelődnek, a periférián élók, a deviánssá válás szempontjából veszélyeztetettek új esélyeket kapnak. A fejlődés mércéje az egymás megértésére és a kölcsönös elônyök elérésére irányuló együttmúködés. 